\title{
Kepuasan Memediasi Pengaruh Kualitas Sistem, Kualitas Informasi dan Pelatihan terhadap Kinerja Individual Pengguna Siskeudes
}

\author{
Hayyun Aini ${ }^{1}$ \\ Fakultas Ekonomi dan Bisnis \\ Universitas Mataram, Indonesia
}

\author{
M. Irwan ${ }^{2}$ \\ Fakultas Ekonomi dan Bisnis \\ Universitas Mataram, Indonesia
}

Surel : hayyunaini09@gmail.com

\section{ABSTRAK}

Penelitian ini bertujuan untuk memberikan bukti secara empiris pengaruh kualitas sistem, kualitas informasi dan pelatihan terhadap kinerja serta pengaruh kepuasan sebagai mediasi pada pengaruh kualitas sistem, kualitas informasi dan pelatihan terhadap kinerja pengguna sistem informasi keuangan desa (SISKEUDES) di Kabupaten Lombok Timur. Metode yang digunakan adalah penelitian eksplanatory dengan pendekatan kuantitatif, dengan sampel sebanyak 71 bendahara desa. Hasil penelitian menunjukkan bahwa kualitas sistem, kualitas informasi dan kepuasan berpengaruh positif dan signifikan terhadap kinerja dan kepuasan memediasi secara parsial pengaruh kualitas sistem, kualitas informasi dan pelatihan terhadap kinerja pengguna sistem informasi keuangan desa (SISKEUDES) di Kabupaten Lombok Timur.

Kata Kunci: Kualitas Sistem; Kualitas Informasi; Pelatihan; Kepuasan; Kinerja.

\section{Satisfaction Mediates the Effect of System Quality, Information Quality and Training on Individual Performance of Siskeudes Users}

\begin{abstract}
This study aims to provide empirically the effect of system quality, information quality and training on performance as well as the effect of mediating satisfaction on the effect of system quality, information quality and training on the performance of village financial information system users (Siskeudes) in East Lombok Regency. The method used is explanatory research with a quantitative approach, with a sample of 71 village treasurers. The results showed that system quality, information quality and satisfaction had a positive and significant effect on performance and satisfaction partially mediated the effect of system quality, information quality and training on the performance of village financial information system users (SISKEUDES) in East Lombok Regency.
\end{abstract}

Keywords: $\quad$ System Quality; Quality Of Information; Training; Satisfaction; Performance.

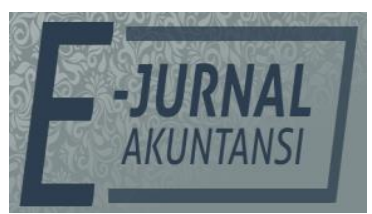

e-ISSN 2302-8556

Vol. 31 No. 9

Denpasar, September 2021 Hal. 2340-2354

DOI:

10.24843/EJA.2021.v31.i09.p15

PENGUTIPAN:

Aini, H., Irwan, M., \& Surasni, N.K. (2021).

Kepuasan Memediasi

Pengaruh Kualitas Sistem, Kualitas Informasi dan

Pelatihan terhadap Kinerja Individual Pengguna Siskeudes. E-Jurnal Akuntansi, 31(9), 2340-2354

RIWAYAT ARTIKEL: Artikel Masuk: 9 Juli 2021

Artikel Diterima: 23 September 2021

Artikel dapat diakses : https://ojs.unud.ac.id/index.php/Akuntansi/index 


\section{PENDAHULUAN}

Aplikasi Sistem Keuangan Desa merupakan sebuah aplikasi pengelolaan keuangan desa yang dikembangkan oleh Badan Pengawasan Keuangan dan Pembangunan yang bertujuan untuk meningkatkan kualitas tata kelola keuangan desa (Atikah et al., 2021). Aplikasi Siskeudes merupakan alat bantu yang diperuntukan untuk Pemerintah Desa dalam Pengelolaan Keuangan Desa mulai dari tahap perencanaan, pelaksanaan, penata usahaan, pelaporan dan pertanggungjawaban secara komputerisasi. Dengan adanya tekhnologi sistem informasi yang digunakan untuk melakukan suatu pekerjaan, secara langsung dapat meningkatkan kinerja lebih tinggi dibandingkan sebelum adanya sistem informasi yang digunakan. Dalam penerapan sistem informasi keuangan tidak lepas pula dari permasalahan-permasalahan yang ada dalam penggunaannya, begitu pun dengan penerapan sistem informasi keuangan desa (Siskeudes) masih juga menemui berbagai macam kendala. Fenomena permasalahan yang berkaitan dengan kinerja bendahara desa sebagai pengguna dari sistem informasi ini, bisa terjadi diseluruh pemerintah desa di Negara Indonesia seperti halnya pemerintah desa di kabupaten Lombok Timur. Hal tersebut dikarenakan sistem informasi keuangan desa ini merupakan hal baru dan tidak dapat secara langsung diterima pengguna, sehingga membutuhkan penyesuaian yang lebih dalam penggunaannya.

Penelitian yang dilakukan oleh Suhud \& Rohman (2015) menunjukkan bahwa kualitas sistem memengaruhi kinerja. Penelitian yang dilakukan oleh Amin (2014) menunjukkan bahwa kualitas sistem berpengaruh terhadap kinerja. Berbeda dengan penelitian Dewi et al., (2017) yang sebaliknya menjelaskan bahwa kualitas sistem tidak memiliki pengaruh terhadap kinerja yaitu semakin baik kualitas sistem namun tidak terdapat kecenderungan meningkatkan kinerja.

Dalam hal kualitas informasi, penelitian yang dilakukan oleh Amin (2014) menunjukkan bahwa kualitas informasi berpengaruh terhadap kinerja. Penelitian Dewi et al., (2017) menyebutkan bahwa kualitas informasi memiliki pengaruh terhadap kinerja. Penelitian selanjutnya yang dilakukan oleh (Hidayat \& Saleh, 2018) menunjukkan bahwa kualitas informasi juga memiliki pengaruh terhadap kinerja dan penelitian Krisdiantoro et al., (2019) menunjukkan bahwa kualitas informasi berpengaruh terhadap kinerja.

Selanjutnya penelitian yang dilakukan oleh Kuruppu et al., (2021) menjelaskan bahwa pelatihan berpengaruh positif dan signifikan terhadap kinerja yang yang berarti bahwa semakin bagus pelatihan yang diikuti maka akan semakin bagus kinerja. Penelitian yang dilakukan oleh Guan \& Frenkel (2019) juga menunjukkan bahwa pelatihan memiliki efek terhadap kinerja. Penelitian yang dilakukan oleh Vokshi (2020) juga menunjukkan bahwa pelatihan berpengaruh terhadap kinerja dan penelitian yang dilakukan oleh Abogsesha \& Kaushik (2017) menunjukkan bahwa pelatihan berpengaruh terhadap kinerja. Namun penelitian yang memliki hasil berbanding terbalik ditunjukkan oleh Aldhukair \& Abunar (2021) yang menunjukkan bahwa pelatihan tidak memengaruhi kinerja. Beberapa hasil penelitian tersebut menunjukan hasil yang berbeda atas pengaruh pelatihan terhadap kinerja, sehingga perlu dilakukan penelitian dengan objek penelitian yang berbeda pada penelitian ini. 
Adanya ketidak konsistenan penelitian terkait dengan pengaruh kualitas sistem, kualitas informasi dan pelatihan terhadap kinerja sehingga menjadi acuan dan dorongan bagi peneliti untuk menambah variabel kepuasan sebagai mediasi. Penelitian yang dilakukan Anjarwati \& Apolo (2019) yang menunjukkan bahwa kualitas sistem dan informasi memiliki pengaruh terhadap kepuasan, penelitian Simaremare \& Isyandi (2015) menunjukkan bahwa pelatihan memiliki pengaruh terhadap kepuasan dan penelitian Saputra et al., (2015) menunjukkan bahwa kepuasan berpengaruh terhadap kinerja, sedangkan penelitian dari Kuruppu et al., (2021) menunjukan bahw kualitas sistem tidak berpengaruh terhadap kepuasan, penelitian dari Amin (2014) menunjukan bahwa kualitas informasi tidak berpengaruh terhada kepuasan dan penelitian dari Aldhukair \& Abunar (2021) menunjukan pelatihan tidak berpengaruh terhadap kepuasan.

Penelitian yang dilakukan ini merupakan penelitian pengembangan dari penelitian Anjarwati \& Apolo (2019), Zaineldeen et al., (2020) dan Puspitasari et al., (2019) dimana peneliti meneliti variabel kualitas sistem, kualitas informasi dan pelatihan secara bersamaan dan menambahkan kepuasan sebagai mediasi. Model penelitian yang dilakukan Zaineldeen et al., (2020) Hipotesis dibangun berdasarkan Theory Reasoned Of action, Theory Technology acceptance models, Theory Human Resource Management, dan Theory DEM Information Success Models, serta beberapa penelitian terdahulu yang berkaitan. Berikut adalah pengembangan hipotesis dari penelitian ini.

Kualitas sistem berperan penting dalam meningkatkan kinerja karena kualitas sistem merupakan faktor penunjang dalam mempermudah pekerjaan pengguna yang menggunakan sistem informasi dalam melakukan pekerjaan. adanya sistem infromasi yang digunakan dapat mempermudah dan memberikan kelancaran dalam pekerjaan. Penelitian yang dilakukan oleh Amin, (2014), Krisdiantoro et al., (2019), Ningrum \& Susilo (2017), dan Suhud \& Rohman (2015) menunjukkan bahwa kualitas sistem berpengaruh terhadap kinerja. Seingga diasumsikan sebagai berikut.

$\mathrm{H}_{1:}$ Kualitas sistem berpengaruh positif terhadap kinerja individual.

Untuk dapat meningkatkan kinerja, kualitas informasi berperan penting sebagai pendorong kinerja tersebut, dimana ketika kualitas informasi yang dihasilkan memiliki kualitas yang baik yang sudah sesuai dengan kriteria maka hal tersebut bisa menajdi salah satu faktor yang secara langsung dapat meningkatkan kinerja penggunanya. Penelitian yang dilakukan oleh Krisdiantoro et al., (2019) dan Hidayat \& Saleh (2018) menunjukkan hasil bahwa kualitas informasi berpengaruh terhadap kinerja Sehingga diasumsikan sebagai berikut. $\mathrm{H}_{2}$ : Kualitas informasi berpengaruh positif terhadap kinerja Individual.

Untuk dapat meningkatkan pemahaman pengguna sistem informasi maka diperlukan pelatihan sebagai sarana atau fasilitas yang dapat dilaksanakan untuk dapat meningkatkan pengetahuan pengguna sehingga dengan meningkatkan pengetahuan pengguna yang secara langsung dapat meningkatkan kinerja. Penelitian yang dilakukan Rifan (2019) dan Agsta \& Sutanto (2013) jmenunjukkan bahwa pelatihan berpengaruh terhadap kinerja. Sehingga diasumsikan sebagai berikut.

$\mathrm{H}_{3}$ : Pelatihan berpengaruh positif terhadap kinerja Individual. 
Kepuasan yang merupakan prilaku memberikan dampak terhadap minat seseorang dalam melakukan sesuatu sehingga hal tersebut dapat memberikan dampak atau manfaat terhadap hal lainnya. Sama halnya dengan kepuasan bendahara desa yang juga merupakan individu yang dapat menimbulkan prilaku yang beragam. Penelitian yang dilakukan oleh Puspitasari et al., (2019), Simaremare \& Isyandi (2015) dan Dewi et al., (2017) menunjukkan bahwa kepuasan berpengaruh terhadap kinerja. Sehingga diasumsikan sebagai berikut.

$\mathrm{H}_{4}$ : Kepuasan berpengaruh positif terhadap kinerja Individual.

Kualitas sistem yang memberikan banyak kemudahan dan manfaat dalam melaksanakan pekerjaan dapat memberikan kepuasan bagi penggunanya. Banyaknya manfaat yang diberikan oleh sistem informasi dapat memberikan perasaan puas bagi penggunanya. Penelitian yang dilakukan oleh (Rukmiyati \& Budiartha (2020) dan Buana \& Wirawati (2018) menunjukkan bahwa kualitas sistem berpengaruh terhadap Kepuasan. Sehingga diasumsikan sebagai berikut $\mathrm{H}_{5:}$ Kualitas sistem berpengaruh positif terhadap kepuasan.

Kualitas informasi yang dihasilkan oleh sistem informasi dapat memberikan pengaruh terhadap prilaku penggunanya, dimana jika kualitas informasi yang dihasilkan oleh sistem informasi sesuai dengan apa yang dibutuhkan dapat memberikan perasaan puas bagi pengguna sistem informasi. Penelitian yang dilakukan oleh Budiartha (2016) menunjukkan bahwa kualitas informasi berpengaruh terhadap Kepuasan. Hasil yang sama juga ditunjukkan oleh penelitian yang dilakukan oleh (Rukmiyati \& Budiartha (2020) dan Apsari \& Astika (2020) menunjukkan bahwa kualitas informasi berpengaruh terhadap Kepuasan. Sehingga diasumsikan sebagai berikut.

$\mathrm{H}_{6:}$ Kualitas informasi berpengaruh positif terhadap kepuasan.

Pengembangan kapasitas diri pengguna sistem informasi untuk dapat memberikan pemahaman terhadap pekerjaan yang dilakukan yang berkaitan dengan penggunaan sistem informasi keuangan desa bisa didapatkan dari pelatihan-pelatihan yang diikuti. Kesesuaian antara apa yang dibutuhkan dengan apa yang diterima dari pelatihan dapat menimbulkan perasaan puas pengguna sistem informasi. Penelitian yang dilakukan oleh Amalia et al., (2016), Rifan (2019), dan Simaremare \& Isyandi (2015) menunjukan bahwa pelatihan berpengaruh signifikan terhadap kepuasan. Sehingga diasumsikan sebagai berikut.

$\mathrm{H}_{7}$ : Pelatihan berpengaruh positif terhadap kepuasan.

Kualitas sistem informasi yang digunakan harus dapat memberikan banyak manfaat dan kemudahan sehingga secara tidak langsung dapat meningkatkan kinerja dikarenakan dengan kualitas sistem informasi yang berkualitas dapat memberikan perasaan puas bagi pengguna sistem informasi yang menjalankannya. Adanya perasaan puas bagi pengguna akan dapat meningkatkan kinerja. Penelitian yang dilakukan oleh Dewi et al., (2017), Rukmiyati \& Budiartha (2020), dan Saputra et al., (2015) menunjukan bahwa kualitas sistem berpengaruh positif terhadap kinerja dengan dimediasi kepuasan. Sehingga diasumsikan sebagai berikut.

$\mathrm{H}_{8:}$ Kualitas sistem berpengaruh positif terhadap kinerja dengan dimediasi kepuasan.

Kualitas informasi yang dihasilkan dari sistem informasi yang digunakan dalam tata kelola keuangan secara tidak langsung dapat meningkatkan kinerjanya 
dikarenakan pengguna sudah merasa puas dengan kualitas informasi yang dihasilkan sehingga hal tersebut dapat meningkatkan kinerjanya secara tidak lansung. Penelitian yang dilakukan oleh Apsari \& Astika (2020), Dewi et al., (2017), Rukmiyati \& Budiartha (2016) dan Saputra et al., (2015) menunjukan bahwa kualitas informasi berpengaruh positif terhadap kinerja dengan dimediasi kepuasan. Sehingga diasumsikan sebagai berikut.

$\mathrm{H}_{9}$ : Kualitas informasi berpengaruh positif terhadap kinerja dengan dimediasi kepuasan.

Pelatihan merupakan salah satu cara untuk dapat meningkatkan kapasitas kerja untuk dapat meningkatkan kinerja. Pelatihan yang diikuti juga harus sesuai dengan apa yang dibutuhkan baik itu terkait dengan kesesuaian materi maupun instruktur sehingga hal tersebut secara tidak langsung dapat meningkatkan kinerja dikarenakan adanya perasaan puas pengguna berkaitan dengan pelatihan yang telah diikuti. Penelitian yang dilakukan Andriyan (2018), Fakhri (2015), Puspitasari et al., (2019); Saputra et al., (2015) dan Simaremare \& Isyandi (2015) menunjukan bahwa pelatihan berpengaruh positif terhadap kinerja dengan dimediasi kepuasan. Sehingga diasumsikan sebagai berikut.

$\mathrm{H}_{10}$ : Pelatihan berpengaruh positif terhadap kinerja dengan dimediasi Kepuasan.

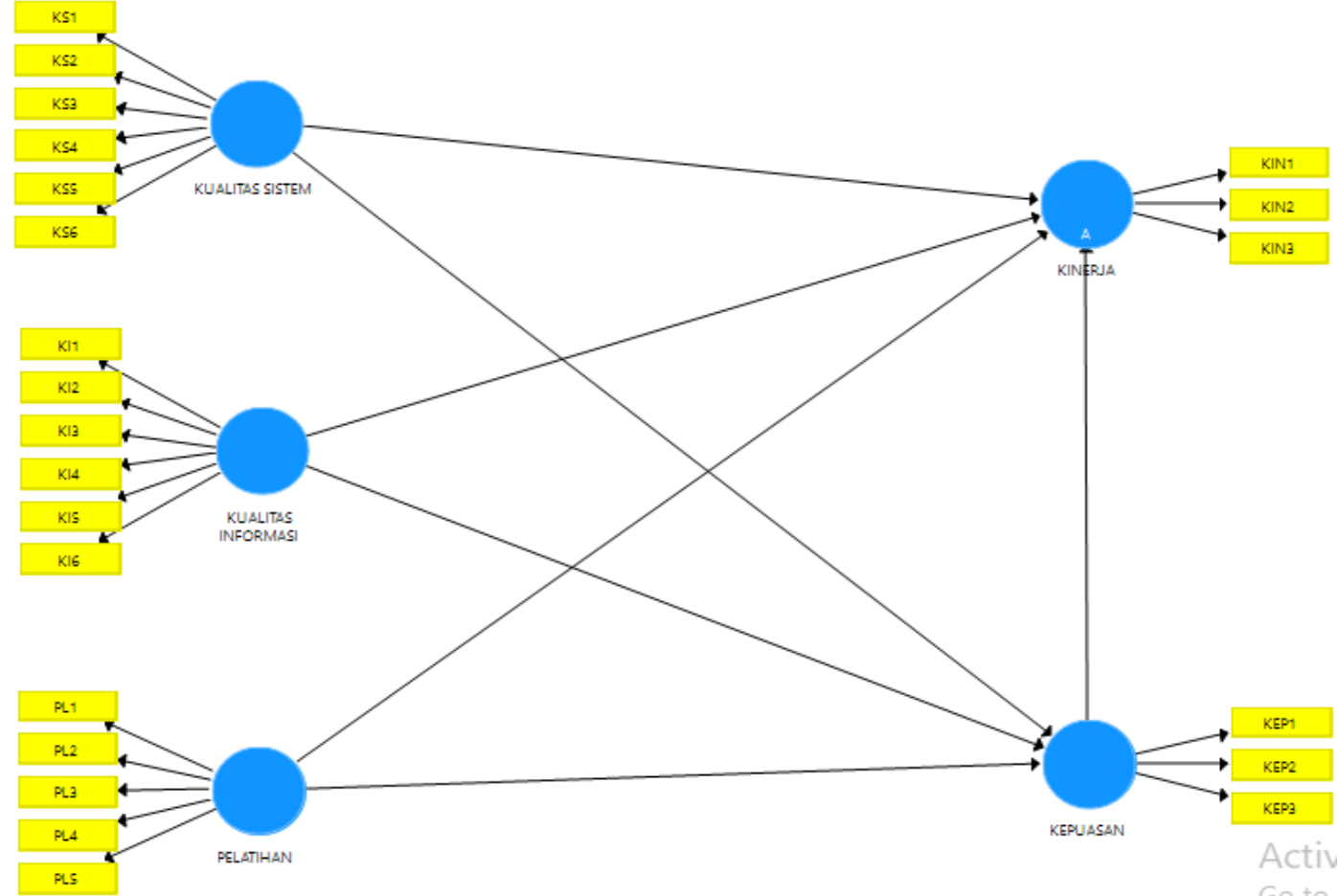

Gambar 1. Model PLS

Sumber: Data Penelitian, 2021

\section{METODE PENELITIAN}

Metode penelitian yang digunakan adalah penelitian eksplanatori dengan pendekatan kuantitatif. Data yang digunakan berupa angka yang didapatkan dari instrumen kuesioner. Menurut Singarimbun dalam Pramanda et al., (2016) eksplanatory research (penelitian eksplanatori) merupakan hubungan kausal antara variabel-variabel melalui pengujian hipotesa. 
Data dikumpulkan menggunakan teknik survey dengan penyebaran kuesioner. Kuesioner merupakan teknik pengumpulan data yang dilakukan dengan cara memberi seperangkat pertanyaan atau pernyataan tertulis kepada responden untuk dijawabnya (Sugiyono, 2014). Sumber data yang digunakan dalam penelitian ini adalah data primer. Data primer diperoleh dari hasil jawaban responden yaitu bendahara desa atas kuesioner/angket yang diberikan.

Populasi dalam penelitian ini adalah seluruh bendahara desa yang ada di Kabupaten Lombok Timur, dimana di Kabupaten Lombok Timur terdapat 239 desa yang masing-masing memiliki satu bendahara desa, sehingga jumlah populasi dalam penelitian ini adalah 239 bendahara desa. Dalam menentukan jumlah sampel yang dicari, pada penelitian ini digunakan rumus slovin karena jumlah populasi dapat diketahui dan berjumlah tidak terlalu besar (Wiratna, 2014). Berikut hasil perhitungan sampel dengan menggunakan rumus slovin dan toleransi eror yang digunakan adalah 10 persen jadi jumlah sampel dalam penelitian ini adalah 70.501 dibulatkan menjadi 71 responden.

Pada penelitian ini digunakan skala Likert sebagai mutu jawaban responden atas pertanyaan yang terkandung dalam dengan bobot skor 1-9 dan alternatif jawaban, Sangat setuju sekali (9), Sangat setuju (8), Setuju (7), Agak Setuju (6), Netral (5), Agak Tidak Setuju (4), Tidak setuju (3), Sangat Tidak Setuju (2) Sama sekali tidak setuju (1). Variabel yang digunakan dalam penelitian ini adalah kualitas sistem, kualitas informasi, pelatihan, kepuasan dan Kinerja. Definisi operasional dan pengukuran variabel adalah sebagai berikut.

Kualitas system merupakan persepsi pengguna atas kemudahan Siskeudes untuk dioperasikan. Indikator pada variabel ini diadopsi berdasarkan penelitian dari Kurnianto et al., (2019) yaitu kualitas data, mudah dipelajari, fungsionalitas, integrasi dan konsisten serta efisien. Kualitas informasi adalah persepsi pengguna atas kualitas Siskeudes dalam memperoleh informasi. Indikator pada variabel ini diadopsi dari Mangkunegara (2016) dengan indikator ketepatan waktu, sesuai kebutuhan akurasi, relevan, berguna, jelas, kelengkapan dan terkini.

Pelatihan merupakan persepsi pengguna Seskeudes atas ketepatan pelatihan yang diberikan. Indikator pada variabel ini diadopsi dari Mangkunegara (2016) dengan indikator tujuan, para pelatih (trainers), materi pelatihan dan pengembangan, peserta pelatihan. Kinerja merupakan penilaian dari pimpinan terhadap hasil kerja dari pengguna Siskeudes. Indikator pada variabel ini diadopsi dari Bernardin \& Russel (2013) dengan indikator Quantity of work, quality of work dan job knowledge. Kepuasan merupakan taraf kepuasan pengguna Siskeudes. Indikator pada variabel ini diadopsi dari Tjiptono \& Chandra., (2017) dengan indikator Overall satisfaction, comparison to ideal, comfirmation of expectation Willingness to recommend.

Data yang telah dikumpulkan selanjutnya dianalisis menggunakan analisis statistik deskriptif dan analisis structural equation model (SEM) PLS. Statistik deskriptif memberikan gambaran suatu data yang dilihat dari nilai rata-rata, tandar deviasi, skewness, varian, maksimum, dan nilai minimum (Ghozali, 2021). Teknik analisis data menggunakan Structural Equation Modeling (SEM) dilakukan untuk menjelaskan secara menyeluruh hubungan antar variabel yang ada dalam penelitian. Menurut minimum Ghozali (2021) tahapan analisis menggunakan SEM-PLS setidaknya harus melalui lima proses tahapan, yaitu konseptualisasi 
model, menentukan metode analisis algorithm, menentukan metode resampling, menentukan diagram jalur, dan evaluasi model.

\section{HASIL DAN PEMBAHASAN}

Keseluruhan loading factor CFA first order menunjukkan bahwa model sudah memenuhi syarat convergent validity karena nilai loading factor sudah lebih dari 0,7 dan nilai $t$ statistic lebih dari 1,65. Artinya seluruh indikator valid sebagai alat ukur untuk variabel pada masing-masing variabel laten kualitas sistem, kualitas informasi, pelatihan, Kepuasan, dan kinerja pengguna. Selanjutnya, hasil pengujian dengan Average Variance Extracted (AVE) memiliki convergent validity yang baik dengan nilai $A V E$ yang lebih besar dari 0,5.

Validitas discriminant berhubungan dengan prinsip bahwa pengukur pengukur (manifest variabel) konstruk yang berbeda seharusnya tidak berkorelasi dengan tinggi. Untuk menguji validitas discriminant pada model dengan indikator refleksif yaitu melalui nilai cross loading untuk setiap variabel, dengan nilai harus lebih dari 0,7. Hasil pengujian validitas diskriminan menunjukkan bahwa setiap indikator memiliki nilai $>0,07$.

Pemeriksaan dan penilaian terhadap validitas diskriminan untuk dapat diterima jika nilai akar kuadrat AVE-nya lebih besar dari nilai korelasi variabel laten tersebut dengan seluruh variabel laten lainnya Fornell dan Lacker dalam (Santosa, 2018). Hasil menunjukkan bahwa bahwa nilai akar kuadrat AVE dan nilai korelasi suatu variabel (konstruk) laten dengan konstruk lainnya menunjukkan nilai yang lebih besar, sehingga dinyatakan valid.

Composite Reliability digunakan dalam menguji reliabilitas suatu konstruk. Rule of thumb yang biasanya digunakan untuk menilai reliabilitas konstruk yaitu nilai Composite Reliability harus lebih besar dari 0,7 Untuk penelitian yang bersifat comfirmatory dan nilai 0,6-0,7 masih dapat diterima untuk penelitian yang bersifat explonatory (Ghozali, 2021). Hasil menunjukkan nilai Composite Reliability dan Cronbachs Alpha dari semua variabel laten $>0,70$, sehingga semua variabel manifest dalam mengukur variabel laten dalam model yang diestimasi dinyatakan reliabel.

Perubahan nilai R-squares $\left(\mathrm{R}^{2}\right)$ digunakan untuk menjelaskan pengaruh variabel laten eksogen tertentu terhadap variabel laten endogen apakah memiliki pengaruh yang subtantif. Nilai $R$-squares $0,75,0,50$ dan 0,25 dapat disimpulkan bahwa model kuat, moderat dan lemah (Ghozali, 2021). Pengaruh besarnya effect size (F2) memiliki kriteria 0,02 dengan arti pengaruh kecil, 0,15 memiliki pengaruh menengah dan 0,35 memiliki pengaruh besar pada level structural.

Disamping melihat besarnya $R$-square, evaluasi model PLS dapat juga dilakukan dengan $Q 2$ predictive relevance atau predictive sample reuse untuk merepresentasi sintetis dari cross-validation dan fungsi fitting dengan prediksi dari observed variabel dan estimasi dari parameter konstruk. Nilai $\mathrm{Q}^{2}>0$ menunjukkan bahwa model mempunyai predictive relevance, sedangkan nilai $\mathrm{Q}^{2}<0$ menunjukkan bahwa model kurang memiliki predictive relevance (Ghozali, 2021:74) Berikut adalah hasil perhitungan $\mathrm{Q}^{2}$.

$$
\mathrm{Q}^{2}=1-\left(1-\mathrm{R}_{1}^{2}\right)\left(1-\mathrm{R}_{2}^{2}\right)=1-(1-0,834)(1-0,512)=0,919
$$

Didapatkan nilai $Q$-square sebesar 0,919 sehingga model layak dikatakan memiliki nilai prediktif yang relevan. Hasil pengaruh jalur langsung dapat dilihat pada tabel path coefficient berikut ini. 
Tabel 1. Path Coefficient

\begin{tabular}{|c|c|c|c|c|c|}
\hline Hipotesis & $\begin{array}{l}\text { Pengaruh Langsung dan } \\
\text { tidak lansung }\end{array}$ & $\begin{array}{l}\text { Original } \\
\text { Sample }\end{array}$ & $\begin{array}{c}\mathrm{T} \\
\text { Statistics }\end{array}$ & $\begin{array}{c}\mathrm{P} \\
\text { values }\end{array}$ & Keterangan \\
\hline$\overline{\mathrm{H}_{1}}$ & Kualitas Sistem > Kinerja & 0,189 & 1,941 & 0,026 & Signifikan \\
\hline $\mathrm{H}_{2}$ & Kualitas Informasi > Kinerja & 0,182 & 2,205 & 0,014 & Signifikan \\
\hline $\mathrm{H}_{3}$ & Pelatihan $>$ Kinerja & 0,226 & 1,934 & 0,027 & Signifikan \\
\hline $\mathrm{H}_{4}$ & Kepuasan $>$ Kinerja & 0,479 & 5,865 & 0,000 & Signifikan \\
\hline $\mathrm{H}_{5}$ & Kualitas sistem $>$ Kepuasan & 0,280 & 1,715 & 0,043 & Signifikan \\
\hline $\mathrm{H}_{6}$ & Kualitas sistem > Kepuasan & 0,261 & 1,833 & 0,034 & Signifikan \\
\hline $\mathrm{H}_{7}$ & Pelatihan $>$ kepuasan & 0,304 & 2,086 & 0,019 & Signifikan \\
\hline $\mathrm{H}_{8}$ & $\begin{array}{l}\text { Kualitas sistem ->Kepuasan - } \\
\text { >Kinerja }\end{array}$ & 0,125 & 1,829 & 0,034 & Signifikan \\
\hline $\mathrm{H}_{9}$ & $\begin{array}{l}\text { Kualitas informasi - } \\
>\text { Kepuasan->Kinerja }\end{array}$ & 0,134 & 1,687 & 0,046 & Signifikan \\
\hline $\mathrm{H}_{10}$ & $\begin{array}{l}\text { Pelatihan ->Kepuasan- } \\
\text { >Kinerja }\end{array}$ & 0,146 & 2,226 & 0,013 & Signifikan \\
\hline $\mathrm{H}_{1}$ & Kualitas Sistem > Kinerja & 0,189 & 1,941 & 0,026 & Signifikan \\
\hline $\mathrm{H}_{2}$ & Kualitas Informasi > Kinerja & 0,182 & 2,205 & 0,014 & Signifikan \\
\hline
\end{tabular}

Sumber: Data Penelitian, 2021

Hipotesis pertama, tentang kualitas sistem berpengaruh terhadap kinerja pengguna dapat diterima. Nilai path coefficient sebesar 0,189 signifikan pada $t$ statistic 1,941 > t-tabel 1,65 dan pada P-value 0,026 < tingkat signifikansi 0,05. Hal ini menunjukkan jika kualitas sistem semakin baik atau tinggi maka kinerja pengguna secara lansung akan meningkat. Hasil penelitian ini sejalan dengan penelitian yang dilakukan oleh Amin (2014), Krisdiantoro et al., (2019), Ningrum \& Susilo (2017) dan Suhud \& Rohman (2015) yang menunjukkan bahwa kualias sistem berpengaruh terhadap kinerja. Hasil tersebut sesuai dengan pendapat dari Davis dalam Hasibuan, (2017) bahwa sistem informasi merupakan data yang telah diolah menjadi suatu data yang berguna bagi penggunanya yang bersifat nyata dan dapat dirasakan nilainya. Sehingga melalui teori tersebut dapat disimpulkan bahwa kualitas sistem berperan penting dalam memudahkan pengguna untuk menyelesaikan pekerjaannya.

Hipotesis kedua, tentang kualitas informasi berpengaruh terhadap kinerja pengguna dapat diterima. Nilai path coefficient sebesar 0,182 signifikan pada $t$ statistic 2,205 > t-tabel 1,65 dan pada P-value 0,014 < tingkat signifikansi 0,05 . Hal ini berarti bahwa jika kualitas informasi yang dihasilkan sistem informasi keuangan desa maka secara lansung akan meningkatkan kinerja penggunanya. Hasil penelitian ini mendukung penelitian yang dilakukan Hidayat \& Saleh (2018), Krisdiantoro et al., (2019) dan Muliawan (2018) yang menunjukkan hasil bahwa kualitas informasi berpengaruh terhadap kinerja. Berdasarkan teori yang dikemukakan oleh Sujarweni (2015) bahwa sistem merupakan rangkaian elemen yang saling berkaitan dan bekerja sama dalam pencapaian tujuan, sehingga dengan kualitas informasi dalam sebuah sistem akan memudahkan pengguna dalam memudahkan serta meningkatkan kinerjanya.

Hipotesis ketiga, tentang pelatihan berpengaruh terhadap kinerja pengguna dapat diterima. Nilai path coefficient sebesar 0,226 signifikan pada t-statistic 1,934> $\mathrm{t}$-tabel 1,65 dan pada P-value 0,026 < tingkat signifikansi 0,05. Hal ini berarti bahwa 
jika pelatihan baik atau tinggi maka kinerja jjuga akan meningkat. Hasil penelitian ini sejalan dengan penelitian yang dilakukan dilakukan Rifan (2019) dan Agsta \& Sutanto (2013) yang menunjukkan bahwa pelatihan mempunyai pengaruh positif yang signifikan terhadap kinerja. Sesuai pendapat dari Mathis \& Jackson (2011) bahwa pelatihan dapat dirancang untuk memungkinkan para karyawan untuk melakukan pekerjaan, tugas dan tanggung jawab mereka dengan baik, pelatihan antar pribadi dan pemecahan masalah, dimaksudkan untuk mengatasi masalah operasional dan antar pribadi serta meningkatkan hubungan dalam pekerjaan organisasional. Dari teori tersebut jelas dikatakan dengan pelatihan seseorang dapat menemukan cara-cara baru untuk menyelesaikan pekerjaannya dan juga meningkatnya kompetensi dasar yang dimilikinya sehingga melalui usaha pelatihan dapat meningkatkan kinerja.

Hipotesis keempat, tentang Kepuasan berpengaruh terhadap kinerja pengguna dapat diterima. Nilai path coefficient sebesar 0,479 signifikan pada $t$ statistic 5,865 > t-tabel 1,65 dan pada P-value 0,000 < tingkat signifikansi 0,05. Hal ini berarti bahwa jika Kepuasan baik atau tinggi maka kinerja juga akan meningkat. Hasil penelitian ini sejalan dengan penelitian yang dilakukan oleh Puspitasari et al. (2019), Simaremare \& Isyandi (2015) dan Dewi et al. (2017) yang menunjukkan bahwa kepuasan berpengaruh terhadap kinerja. Sesuai pendapat yang dikemukakan oleh Hasibuan (2017) bahwa kinerja karyawan adalah suatu hasil yang dicapai oleh seorang dalam melaksanakan tugas-tugas yang dibebankan kepadanya yang didasarkan atas kecakapan, pengalaman dan kesungguhan serta waktu, dalam kondisi tersebut berarti bahwa pengguna Siskeudes merasakan kepuasannya dalam menggunakan Siskeudes sehingga membentuk kinerja yang baik pada setiap pengguna Siskeudes.

Hipotesis kelima, tentang kualitas sistem berpengaruh terhadap kepuasan pengguna dapat diterima. Nilai path coefficient sebesar 0,280 signifikan pada $t$ statistic 1,715 > t-tabel 1,65 dan pada P-value 0,043 < tingkat signifikansi 0,05. Hal ini berarti bahwa jika kualitas sistem baik atau tinggi maka Kepuasan juga akan meningkat atau tinggi. Hasil penelitian ini sejalan dengan penelitian yang dilakukan oleh Buana \& Wirawati (2018) dan Rukmiyati \& Budiartha (2016) yang menunjukkan bahwa kualitas sistem berpengaruh positif pada Kepuasan. Sesuai teori yang diungkapkan Tjiptono \& Chandra., (2017) bahwa kepuasan merupakan perasaan dimana terjadinya kesesuaian harapan dengan pemenuhan harapan, maka berdasarkan teori tersebut terjadinya kepuasan didorong oleh pemenuhan kualitas Siskeudes memudahkan pengguna dalam mendapatkan informasi tentang keuangan desa.

Hipotesis keenam, tentang kualitas informasi berpengaruh terhadap Kepuasan dapat diterima. Nilai path coefficient sebesar 0,261 signifikan pada $t$ statistic 1,833 > t-tabel 1,65 dan pada P-value 0,034 < tingkat signifikansi 0,05. Hal ini berarti bahwa jika kualitas informasi baik atau tinggi maka Kepuasan juga akan meningkat atau tinggi. Hasil dari peneliitian ini sejalan dengan Penelitian yang dilakukan oleh Apsari \& Astika (2020), dan Rukmiyati \& Budiartha (2016) menunjukkan bahwa kualitas informasi berpengaruh terhadap Kepuasan. Sesuai teori yang diungkapkan Tjiptono \& Chandra (2017) bahwa kepuasan merupakan perasaan dimana terjadinya kesesuaian harapan dengan pemenuhan harapan 
maka pemenuhan harapan pengguna Siskeudes atas kualitas informasi yang diperlukannya memberikan kepuasan.

Hipotesis ketujuh, tentang pelatihan berpengaruh terhadap Kepuasan, dapat diterima. Nilai path coefficient sebesar 0,304 signifikan pada t-statistic 2,086 > $\mathrm{t}$-tabel 1,65 dan pada P-value 0,019 < tingkat signifikansi 0,05. Hal ini berarti bahwa jika kualitas informasi baik atau tinggi maka Kepuasan juga akan meningkat atau tinggi. Hasil penelitian ini sejalan dengan penelitian yang dilakukan oleh Amalia et al., (2016), Rifan (2019), dan Simaremare \& Isyandi (2015) dengan Hasil penelitian membuktikan aspek pelatihan memiliki pengaruh positif dan signifikan terhadap kepuasan. Sesuai pendapat dari Mathis \& Jackson (2011) bahwa pelatihan dapat dirancang untuk memungkinkan para karyawan untuk melakukan pekerjaan, tugas dan tanggung jawab mereka dengan baik, pelatihan antar pribadi dan pemecahan masalah, sehingga dengan pelatihan para pengguna Siskeudes dapat menguasai operasional dari Siskeudes sehingga pada tahap tersebut para pengguna Siskeudes merasakan kepuasannya atas manfaat dari pelatihan.

Hipotesis kedelapan, tentang kualitas sistem berpengaruh terhadap kinerja pengguna melalui Kepuasan dapat diterima. Nilai koefisien jalur sebesar 0,125, nilai $t$-statistic $1,829>\mathrm{t}$-tabel 1,65 dan pada $P$-value $0,034<$ tingkat signifikansi 0,05 . Hal ini berarti bahwa pengaruh kualitas sistem terhadap kinerja dimediasi oleh kepuasan. Dalam penelitian ini Hasil uji Pengaruh Kualitas system terhadap Kinerja Signifikan dan Hubungan tidak langsungnya juga signifikan, maka dapat dikatakan bahwa Kepuasan memediasi pengaruh langsung Kualitas system terhadap Kinerja secara parsial. Hal ini berarti bahwa ada atau tidaknya Variabel mediasi kepuasan pada pengaruh kualitas sistem terhadap kinerja tidak akan mempengaruhi hubungan langsungnya. Hasil penelitian ini sejalan dengan penelitian yang dilakukan oleh Dewi et al., (2017), Rukmiyati \& Budiartha (2016) dan Saputra et al., (2015) yang menunjukkan bahwa kualitas sistem berpengaruh positif pada kinerja dengan dimediasi kepuasan. Sesuai dengan teori yang dikemukakan Davis (dalam Hasibuan, 2017) bahwa sistem informasi merupakan data yang telah diolah menjadi suatu data yang berguna bagi penggunanya yang bersifat nyata dan dapat dirasakan nilainya, di saat para pengguna dapat merasakan nilai dari kualitas sistem maka para pengguna Siskeudes dapat menyelesaikan pekerjaannya dengan baik, dan dalam keadaan mampu menyelesaikan pekerjaannya tersebut para pengguna merasakan kepuasannya terlebih dahulu atas kualitas sistem yang diberikan dari Siskeudes sehingga pengguna dapat menyelesaikan pekerjaannya dengan berkualitas.

Hipotesis kesembilan, dimana kualitas informasi berpengaruh terhadap kinerja pengguna melalui Kepuasan dapat diterima. Nilai koefisien jalur sebesar 0,134 , nilai $t$-statistic $1,687>\mathrm{t}$-tabel 1,65 dan pada $P$-value $0,046<$ tingkat signifikansi 0,05 . Hal ini berarti bahwa pengaruh kualitas Informasi terhadap kinerja dimediasi oleh kepuasan. Dalam penelitian ini Hasil uji Pengaruh Kualitas informasi terhadap Kinerja Signifikan dan Hubungan tidak langsungnya juga signifikan, maka dapat dikatakan bahwa Kepuasan memediasi pengaruh langsung Kualitas informasi terhadap Kinerja secara parsial. Hal ini berarti bahwa ada atau tidaknya Variabel mediasi kepuasan pada pengaruh kualitas informasi terhadap kinerja tidak akan mempengaruhi hubungan langsungnya. Hasil Penelitian ini sejalan 
dengan penelitian yang dilakukan oleh Apsari \& Astika (2020), Budiartha (2016), Dewi et al., (2017), Rukmiyati \& Budiartha (2016) dan Saputra et al., (2015) bahwa kualitas informasi berpengaruh positif terhadap kinerja dengan dimediasi kepuasan. Sesuai dengan pendapat Davis (dalam Hasibuan, 2017) bahwa sistem informasi merupakan data yang telah diolah menjadi suatu data yang berguna bagi penggunanya yang bersifat nyata dan dapat dirasakan nilainya, sehingga dari teori tersebut dapat dijelaskan bahwa kualitas informasi yang didapatkan para pengguna Siskeudes akan memberikan kepuasan dalam memenuhi kebutuhan mereka atas kualitas informasi keuangan desa seingga dengan terpenuhinya kepuasan tersebut akan meningkatkan hasil kerja mereka dalam hal yang berhubungan dengan keuangan desa.

Hipotesis kesepuluh, dimana pelatihan berpengaruh terhadap kinerja pengguna melalui Kepuasan dapat diterima. Nilai koefisien jalur sebesar 0,146, nilai $t$-statistic $2,226>\mathrm{t}$-tabel 1,65 dan pada $P$-value $0,013<$ tingkat signifikansi 0,05 . Hal ini berarti bahwa pengaruh Pelatihan terhadap kinerja dimediasi oleh kepuasan. Dalam penelitian ini Hasil uji Pengaruh Pelatihan terhadap Kinerja Signifikan dan Hubungan tidak langsungnya juga signifikan, maka dapat dikatakan bahwa Kepuasan memediasi pengaruh langsung Pelatihan terhadap Kinerja secara parsial. Hal ini berarti bahwa ada atau tidaknya Variabel mediasi kepuasan pada pengaruh Pelatihan terhadap kinerja tidak akan mempengaruhi hubungan langsungnya. Hasil penelitian ini sejalan dengan penelitian yang dilakukan Andriyan (2018), Puspitasari et al., (2019), Saputra et al., (2015) dan Simaremare \& Isyandi (2015) dengan hasil penelitian membuktikan aspek pelatihan memiliki pengaruh positif dan signifikan terhadap kepuasan. Sesuai pendapat yang dikemukakan oleh Rivai (2014) bahwa pelatihan merupakan proses secara sistematis mengubah tingkah laku pegawai untuk mencapai tujuan organisasi, hal tersebut menjelaskan bahwa dengan pelatihan keahlian dan kemampuan pengguna Siskeudes untuk melaksanakan pekerjaannya yang berhubungan dengan keuangan desa dapat meningkat, dan peningkatan kemampuan kerja atau kinerja dari pengguna Siskeudes tersebut terjadi karena efek pelatihan yang membuat mereka mampu mengoprasikan Siskeudes.

Hasil penelitian ini mempunyai tiga implikasi yaitu impllikasi teoritis, implikasi praktis dan implikasi kebijakan. Dengan semakin luasnya penelitian yang dilakukan dalam ruang lingkup pemerintahan maka akan dampak memberikan berbagai macam masukan yang berkaitan dengan kondisi pemerintahan khususnya di Kabupaten Lombok Timur. Secara Praktis, penelitian ini dapat dijadikan informasi untuk pemerintah daerah di Kabupaten Lombok Timur dalam meningkatkan kinerja para pengguna Siskeudes melalui usaha pemenuhuan kualitas sistem, kualitas informasi dan pelatihan dalam mengoprasikan Siskeudes sehingga dengan usaha tersebut dapat memberikan kepuasan para pengguna Siskeudes yang akan berdampak pada peningkatan hasil kerja dan prestasi kerja para pengguna Siskeudes.

\section{SIMPULAN}

Kualitas sistem berpengaruh signifikan terhadap kinerja pengguna. Kualitas informasi berpengaruh signifikan terhadap kinerja pengguna. Kepuasan berpengaruh signifikan terhadap kinerja pengguna. Pelatihan berpengaruh 
signifikan terhadap kinerja pengguna. Kualitas sistem berpengaruh signifikan terhadap Kepuasan. Kualitas informasi berpengaruh signifikan terhadap Kepuasan. Pelatihan berpengaruh signifikan terhadap Kepuasan. Kualitas sistem berpengaruh signifikan terhadap kinerja pengguna melalui Kepuasan, dimana kepuasan memediasi pengaruh kualitas system terhadap kinerja secara parsial. Kualitas informasi berpengaruh signifikan terhadap kinerja pengguna melalui Kepuasan, dimana kepuasan memediasi pengaruh kualitas informasi terhadap kinerja secara parsial. Pelatihan berpengaruh signifikan terhadap kinerja pengguna melalui Kepuasan, dimana kepuasan memediasi pengaruh pelatihan terhadap kinerja secara parsial.

Disarankan bagi pemerintah daerah dan dinas yang mengatur pemerintahan desa, untuk terus memperhatikan kebutuhan pengguna sistem informasi, sehingga dapat meningkatkan kinerja untuk dapat mencapai tujuan yang telah ditetapkan. BPKP selaku pembuat sistem informasi keuangan, juga diharapkan untuk terus dapat meningkatkan kualitas sistem informasi sehingga kesalahan-kesalahan yang sering terjadi bisa diatasi, dan jika masih terdapat kekurangan agar dapat terus melakukan update. Pemerintah daerah dan dinas yang menangani pemerintahan desa diharapkan dapat memberikan pelatihanpelatihan minimal dua kali dalam satu tahun dan waktu durasi pelatihannya lebih lama supaya lebih maksimal. Pemerintah daerah diharapkan dapat menyiapkan anggaran tersendiri untuk dapat memberikan pelatihan terhadap pengguna sistem informasi sehingga dapat meningkatkan kapasitas diri dan pengetahuan berkaitan dengan tekhnologi sistem informasi.

Keterbatasan yang ada dalam penelitian ini ialah hanya menganalisa tentang sistem keuangan desa, sedangkan banyak sekali sistem informasi yang berhubungan dengan kinerja pegawai di pemerintahan desa, sehingga disarankan untuk penelitian selanjutnya melakukan penelitian pada sitem-sistem yang digunakan pada pemerintahan desa untuk menunjang efektivitas kinerja para pegawai pemerintahan desa.

\section{REFERENSI}

Abogsesha, A. ., \& Kaushik, G. (2017). Impact of Training and Depelopment on Employee Performance: A Study of Libyan Bank. IJCESC, 4(3), 206-222.

Agsta, L., \& Sutanto, E. M. (2013). Pengaruh Pelatihan Dan Motivasi Kerja Terhadap Kinerja Karyawan Cv Haragon Surabaya. Agora, 1(3), 1.

Aldhukair, H., \& Abunar, M. (2021). Employee Training and Depelopment for Improved Performance. Journal of Archeology of Egyp, 18(2), 107-116.

Amalia, R., Ridwan, \& Bakry, M. I. (2016). Pengaruh Dukungan Top Management, Pelatihan Pengguna SIA, Kemampuan Tehnik Personal SIA Terhadap Kepuasaan Pengguna SIA. E Jurnal Katalogis, 4(9), 83-94.

Amin, M. A. (2014). The Quality Of Information Systems And The Quality Of Information On Performance Of Employees To Mediation System User Satisfaction System Satisfaction Kualitas Informasi Dan Kualitas Sistem Kepuasan Sistem. Jurnal Analisis Bisnis Ekonomi, 12(1), 97-109.

Andriyan, M. R. (2018). Pengaruh Pelatihan dan Lingkungan Kerja Terhadap Kinerja Karyawan Dengan Kepuasan Kerja Sebagai Variabel Intervening. Journal of Materials Processing Technology, 1(1), 1-8. 
Anjarwati, S., \& Apolo. (2019). Several Influences of System Information Quality to User Satisfaction and Its Implication on Individual Performance. Jurnal Ilmiah Manajemen Fakultas Ekonomi, 4(1), 19-30.

Apsari, I. A. P., \& Astika, I. B. P. (2020). Pengaruh Kualitas Informasi, Kualitas Sistem Informasi, dan Perceived Usefulness pada Kepuasan Pengguna SIMDA. E-Jurnal Akuntansi Universitas Udayana, 30(3), 611-623. https://doi.org/https://doi.org/10.24843/EJA.2020.v30.i03.p05

Atikah, S., Rakhmawati, I., Dwi Astuti, B. R., \& Nabila, D. T. Della. (2021). Evaluasi Aplikasi Sistem Keuangan Desa (Siskeudes). Jurnal Aplikasi Akuntansi, 5(2), 161-174. https://doi.org/10.29303/jaa.v5i2.100

Bernardin, H. J., \& Russel, J. E. . (2013). Human Resource Management. McgrawHill. Buana, I. B. G. M., \& Wirawati, N. G. P. (2018). Pengaruh Kualitas Sistem Informasi , Kualitas Informasi , dan Perceived Usefulness Pada Kepuasan Pengguna Sistem Informasi Akuntansi Fakultas Ekonomi dan Bisnis Universitas Udayana ( Unud ), Bali , Indonesia Fakultas Ekonomi dan Bisnis Universitas Udayana. E-Jurnal Akuntansi Universitas Udayana, 22(1), 683-713.

Budiartha, I. K. (2016). Pengaruh Kualitas Sistem Informasi, Kualitas Informasi Dan Perceived Usefulness Pada Kepuasan Pengguna Akhir Software Akuntansi. E-Journal Ekonomi Bisnis Dan Akuntansi Universitas Udayana, 1, 115-142.

Dewi, P. A. R., Badera, I. D. N., \& Wirama., D. G. (2017). Dukungan Manajemen Puncak, Kualitas Sistem, Kualitas Informasi Sebagai Prediktor Kepuasan Pengguna Dan Implikasinya Pada Kinerja Pegawai. E-Jurnal Ekonomi Dan Bisnis Universitas Udayana, 6(6), 2529-2552.

Fakhri, R. F. (2015). Pengaruh Kompensasi Dan Pelatihan Terhadap Kinerja Karyawan Dengan Kepuasan Kerja Sebagai Variabel Intervening. Universitas Diponegoro.

Ghozali, I. (2021). Partial Least Squares Konsep, Tekhnik Dan Aplikasi (3rd ed.). Badan Penerbit Universitas Diponegoro.

Guan, X., \& Frenkel, S. (2019). How perceptions of training impact employee performance: Evidence from two Chinese manufacturing firms. Personnel Review, 48(1), 163-183. https:/ / doi.org/10.1108/PR-05-2017-0141

Hasibuan, M. S. P. (2017). Manajemen Sumber Daya Manusia (Revisi). PT Bumi Aksara.

Hidayat, A., \& Saleh, M. (2018). Kualitas Sistem Dan Kualitas Informasi Pemasaran Terhadap Kinerja Karyawan Di Pt. Inti. SAINTIFIKA ISLAMICA: Jurnal Kajian Keislaman, 4(2), 201-220. http://jurnal.uinbanten.ac.id/index.php/saintifikaislamica/article/view/1 207

Krisdiantoro, Y., Subekti, I., \& Prihatiningtias, Y. W. (2019). Pengaruh Kualitas Sistem dan Kualitas Informasi terhadap Manfaat Bersih dengan Intensitas Penggunaan sebagai Variabel Mediasi. Jurnal Akuntansi Aktual, 5(3), 261-279. https:// doi.org/10.17977/um004v5i32019p261

Kuruppu, C. ., Kavirathne, C. S., \& Karunarathna, N. (2021). The Impact of Training on Employee Performance in a Selected Apparel Sector Organization in Sri Lanka. Global Journal of Management and Business Research, 21(2), 13-20. https://doi.org/10.34257/gjmbravol21is2pg13

Mangkunegara, A. (2016). Manajemen Sumber Daya Manusia Perusahaan. Remaja 
Rosdikarya.

Mathis, R. L., \& Jackson, J. . (2011). Human Resource Management. Salemba Empat. Muliawan, D. (2018). Pengaruh Kualitas Sistem, Kualitas Informasi Dan Kualitas Layanan Sistem Cloud Accounting Terhadap Kinerja Individu Melalui Kepuasan Pengguna Sebagai ... Jurnal Ilmiah Mahasiswa FEB, 6(2).

Ningrum, I., \& Susilo, H. (2017). Pengaruh Kualitas Sistem Informasi Dan Lingkungan Kerja Terhadap Kinerja Karyawan (Studi pada PT Pembangkitan Jawa Bali Unit Pembangkitan Paiton). Jurnal Administrasi Bisnis S1 Universitas Brawijaya, 47(1), 165-171.

Pramanda, R. P., Astuti, E. S., \& Azizah, D. F. (2016). Pengaruh Kemudahan dan Kemanfaatan Penggunaan Tekhnologi informasi Terhdap Kinerja Karyawan ( Studi pada Karyawan Kantor Pusat Universitas Brawijaya ). Jurnal Administrasi Bisnis, 39(2), 117-126.

Puspitasari, D., Suddin, A., \& Sutarno. (2019). Analisis Pengaruh Pelatihan Dan Kompensasi Terhadap Kinerja Perawat Dengan Kepuasan Kerja Sebagai Variabel Mediasi (Survei pada Perawat RSUD Dr. Harjono S. Kabupaten Ponorogo). 13(1), 132-142.

Rifan, P. (2019). Pengaruh Pelatihan, Lingkungan Kerja, dan Budaya Organisasi terhadap Kinerja Karyawan dengan Kepuasan Kerja sebagai Variabel Intevening di Sekretariat Badan Pelatihan dan Pendidikan Keuangan (BPPK) Jakarta. Jurnal Ekonomi, 1(3), 113-165. https:/ / dspace.uii.ac.id/handle/1

Rivai, V. (2014). Manajemen Sumber Daya Manusia Untuk Perusahaan. Raja Grafindo.

Rukmiyati, N. M. S., \& Budiartha, I. K. (2020). Pengaruh Kualitas Sistem, Kualitas Informasi Dan Perceived Usefulness Terhadap Kepuasan Pengguna Sistem Informasi Akuntansi. E-Jurnal Ekonomi Dan Bisnis Universitas Udayana, 1(1), 115-142. https://doi.org/10.31154/kar.v1i2.475.1-11

Rukmiyati, N. M. S., \& Budiartha, I. K. (2016). Pengaruh Kualitas Sistem Informasi, Kualitas Informasi Dan Perceived Usefulness Pada Kepuasan Pengguna Akhir Software Akuntansi. E-Jurnal Ekonomi Dan Bisnis Universitas Udayana, $1(1), 115-142$.

Saputra, F., Oktaroza, M. L., \& Nurhayati, N. (2015). Pengaruh Kepuasan Pengguna Sistem Informasi Akuntansi terhadap Kinerja Karyawan pada PT Nio Farma Tbk . Bandung. Universitas Islam Bandung Repository, 2015-2018.

Simaremare, C. D., \& Isyandi, H. B. (2015). Pengaruh Pelatihan , Lingkungan Kerja Fisik dan Kepemimpinan Terhadap Kepuasan Kerja dalam Meningkatkan Kinerja Karyawan Pada PT. Federal Internasional Finance Wilayah Riau. Jurnal Tepak Manajemen, VII(3), 377-387.

Sugiyono. (2014). Metode Penelitian Bisnis. Alfabeta.

Suhud, S. P., \& Rohman, A. (2015). Pengaruh Penerapan Sistem Informasi Akuntansi Terhadap Kinerja Individu Pegawai Distro Di Kota Bandung. Diponegoro Journal Of Accounting, 4(3), 1-11. https://doi.org/10.1017/9781316414880.007

Sujarweni, V. Wiratna. (2014). Metode Penelitian. pustakabaru press.

Sujarweni, V.W. (2015). Sistem Akuntansi. Pustaka Baru Press.

Tjiptono, F., \& Chandra., G. (2017). Pemasaran Strategik. Andi.

Vokshi, B. (2020). Effect of Training on Employee Performance. International Journal of Economic, Commerce and Management, 8(12), 277-286. 
Zaineldeen, S., Koffi, A. L., \& Hongbo. (2020). Review of The DeLone and McLean Model of Information Systems Success' Background and it's An application in The Education Setting, and Association Linking with Technology Acceptance Model. International Journal of Research in Social Science, 10(9), 99109. 